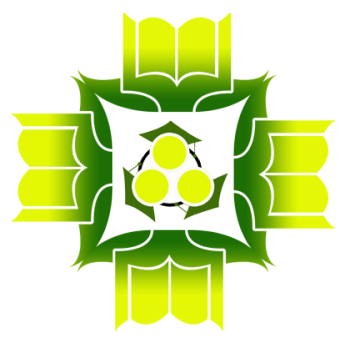

\title{
CITRA APPLICATION: ELEMENTS OF FOLKLORE IDENTIFICATION
}

\author{
Arif Setiawan \\ Universitas Muhammadiyah Malang \\ arifsetiawan@umm.ac.id \\ Aninda Nidhommil Hima \\ Universitas Muhammadiyah Malang \\ aninda@umm.ac.id
}

\begin{abstract}
Folklore in Indonesian language learning is an interesting object of study to discuss. Due to the lack of students' knowledge about folklore, requires an application that can help and facilitate students in learning folklore. Therefore, this study aims to describe the Citra (Cerita Rakyat) Applications to facilitate the identification of folklore elements in fifth-grade elementary school students in Malang. This research uses the descriptive percentage method. The research population in this study were fifth grade students from SD Muhammadiyah 1 Malang, SD Muhammadiyah 4 Malang, SD Muhammadiyah 6 Malang, and SDN 1 Tlogomas. There are 40 students in total from the four elementary schools used as research samples taken by simple random sampling technique. Data collection techniques used interviews and surveys. The data analysis technique used is descriptive analysis. The results of the study show that (1) the application of the Citra to facilitate the identification of folklore elements in Indonesian language learning, and (2) the existence of the Citra Application can also act as a learning medium that can provide benefits for students.
\end{abstract}

Keywords: Learning Folklore, Citra Application, Elementary School in Malang City.

\begin{abstract}
Abstrak
Cerita rakyat dalam pembelajaran bahasa Indonesia merupakan sebuah objek kajian yang menarik untuk diteliti. Hal ini dikarenakan minimnya pengetahuan siswa mengenai cerita rakyat, sehingga memerlukan sebuah aplikasi yang dapat membantu dan memudahkan siswa dalam belajar cerita rakyat. Penelitian ini
\end{abstract}


bertujuan mendeskripsikan penerapan Aplikasi Citra (Cerita Rakyat) guna memudahkan identifikasi unsur cerita rakyat pada siswa Kelas V SD di Kota Malang. Penelitian ini menggunakan metode deskriptif kuantitatif. Populasi penelitian dalam penelitian ini adalah siswa kelas $V$ dari SD Muhammadiyah 1 Malang, SD Muhammadiyah 4 Malang, SD Muhammadiyah 6 Malang, dan SDN 1 Tlogomas. Total terdapat 40 siswa dari keempat Sekolah Dasar yang digunakan sebagai sampel penelitian yang diambil dengan teknik simple random sampling. Teknik pengumpulan data menggunakan wawancara dan kuesioner. Teknik analisis data yang digunakan adalah analisis deskriptif. Hasil penelitian menunjukkan bahwa (1) penerapan Aplikasi Citra (Cerita Rakyat) mampu memudahkan identifikasi unsur cerita rakyat dalam pembelajaran bahasa Indonesia dan (2) keberadaan Aplikasi Citra (Cerita Rakyat) juga dapat berperan sebagai media pembelajaran yang dapat memberikan manfaat bagi siswa.

Kata Kunci: Pembelajaran Cerita Rakyat, Penerapan Citra (Cerita Rakyat), SD di Kota Malang.

\section{INTRODUCTION}

Based on Government Regulation (PP) Number 57 of 2021 concerning National Standards for Indonesian Language Education, it is a mandatory subject that must be taught in schools (Mulyana, 2018). In line with Government Regulation (PP) Number 57 of 2021, the Decree of the Director-General of Higher Education of the Ministry of National Education of the Republic of Indonesia number 43/DIKTI/Kep/2006, also explains that Indonesian language courses are compulsory subjects and are included in the personality development course (Hidayat, et al, 2019). This further strengthens that Indonesian is a subject and subject that must be attended at the elementary to tertiary education level (Hidayat, et al, 2019; Mulyana, 2018). Referring to the two regulations, the role of Indonesian language subjects is very fundamental in the presentation of the basic education curriculum to higher education (Anatasya et al., 2007; Hidayah, 2015; Susilo \& Ramdiati, 2019). This is reinforced by the presentation of standard competences for Indonesian language subjects in elementary schools that describe mastery of knowledge, language skills, and positive attitudes towards Indonesian language and literature (Susilo \& Ramdiati, 2019; Werdiningsih, 2015). These standard competences are the basis for students to understand and respond to local, regional, national, and global situations (Harlina \& Wardarita, 2020; Simbolon, 2016). 
Indonesian language subjects in elementary schools are very important in education because Indonesian subjects function as a tool for thinking logically and critically (Farhurohman, 2017; Handayani \& Subakti, 2021). In addition, Indonesian language subjects are also a means to hone thinking skills and develop students' potential in elementary schools (Dasem, et al, 2018; Dewi \& Yuliana, 2018; Handayani \& Subakti, 2021). Indonesian language subjects in elementary school grade $\mathrm{V}$ on Competency Standard 1 about understanding the explanations of resource persons and folklore orally. In this standard competence 1, students are asked to identify the elements of stories about folk tales they have heard. The purpose of identifying elements of folklore is that students can identify characters, characters, themes, and mandates of folklore (Hadi, 2019; Nurdiyanti \& Suryanto, 2010; Vuri, 2016).

The purpose of identifying elements of folklore is to facilitate the students identify characters, characters, themes, and mandates of folklore. However, in reality, learning to identify elements of folklore still has many obstacles in its implementation. There are still many students who have difficulty in identifying elements of folklore due to the low ability of students (Azis, 2018; Susilo, 2020). Another factor that becomes an obstacle in the learning process to identify elements of folklore is the low interest in learning Indonesian (Anzar \& Mardhatillah, 2018; Bachtiar \& Sihes, 2016). This is because students have the assumption that Indonesian language subjects are boring and uninteresting subjects (Asrial, et al, 2019; Manshur, 2020; Ngumpriyatun, 2020). In addition, students' difficulties in identifying elements of folklore are also based on the use of classical learning models (Harlina \& Wardarita, 2020; Suryanto \& Waluyo, 2017), as well as the lack of learning media used by teachers in delivering folklore material (Bermawi \& Fauziah, 2016; Hadi, 2019).

This condition is also strengthened by the results of observations made, it was found that students still have difficulty in identifying elements of folklore, one of the causes is the lack of learning media about folklore. This is indicated by the number of elementary school students who have not been able to identify folklore, so they still have difficulty identifying the characters, characters, themes, and mandates of folklore (Hadi, 2019; Nurdiyanti \& Suryanto, 2010; Vuri, 2016). In addition, the facilities or learning media in schools are still not supportive to 
organize learning to identify folklore. Based on these conditions, it encourages researchers to create the software as a learning medium in the form of Citra Applications. It is hoped that through this Citra Application the learning process to identify folklore will no longer be a difficult thing for students so that the Basic Competence (KD) that will be achieved in learning Indonesian figurative language can be achieved.

In relation to research on learning Indonesian standard competence and basic competence to identify folklore, various studies that have conducted studies related to folklore have been carried out. Frequent research on Indonesian language learning in elementary schools (Anatasya et al., 2007; Anzar \& Mardhatillah, 2018; Azis, 2018; Bachtiar \& Sihes, 2016; Handayani \& Subakti, 2021; Hidayah, 2015; Mansyur, 2018; Riyanton \& Wijayawati, 2020; Simbolon, 2016; Susilo, 2020; Susilo \& Ramdiati, 2019; Werdiningsih, 2015). Other studies that focus more on learning Indonesian SK \& KD identify folklore in elementary schools (Aini \& Nugraheni, 2021; Anafiah, 2015; Ayu, et al, 2019; Lisnawati, 2021; Parmini, 2015; Suryanto \& Waluyo, 2017; Widyahening \& Rahayu, 2021; Youpika \& Zuchdi, 2016). On the other hand, research that examines Indonesian standard competence and basic competence to identify folklore in elementary schools using software applications has never been done. This kind of research will be able to reveal a variety of valuable information that can be used as a basis for fighting the learning process, especially learning Indonesian SK \& KD identifying folklore in elementary schools. In addition, this information can also be used as an evaluation of how optimal the implementation of Indonesian language learning SK \& KD is to identify folklore in elementary schools. Therefore, the purpose of this study is to describe the application of the Citra Application to assist and facilitate the process of identifying elements of folklore in elementary school students in Malang City.

\section{METHODS}

This study uses the descriptive quantitative research design as it can help researchers to find and determine data, as well as describe the results of the study. In total there are 26 students at SD Muhammadiyah 1 Malang (15 female and 11 male students), 25 students (10 female and 15 male students) at SD 
Muhammadiyah 4 Malang, 23 students (10 female and 13 male students) t SD Muhammadiyah 6 Malang, and 26 students (16 female and 10 male students) at SDN1 Tlogomas Malang. The simple random sampling then was used to determine the research sample, There are 40 students from the four elementary schools used as research samples (10 students taken from each school). The selection of 40 samples from four elementary schools (SD) was due to the Indonesian language subject matter which discussed folklore. The research was conducted in JanuaryFebruary 2020 at SD Muhammadiyah 1 Malang, SD Muhammadiyah 4 Malang, SD Muhammadiyah 6 Malang, and SDN 1 Tlogomas.

Data collection instruments in this study used interviews and questionnaires. Interviews were conducted on 9 students at SD Muhammadiyah 1 Malang, SD Muhammadiyah 4 Malang, SD Muhammadiyah 6 Malang, and SDN 1 Tlogomas which were semi-formal to obtain information about Citra Applications (People's Stories). The questionnaire that has been prepared consists of 10 closed-ended questions and 9 open-ended questions. The questions are closed to explore students' understanding of folklore before using the Citra Application, while open questions are to explore students' understanding of folklore after using the Citra Application. The data analysis technique used in this research is descriptive. Descriptive analysis was used to obtain data on the effectiveness of the application of Citra in learning Indonesian with KI and KD folklore in elementary schools. Data analysis is done by selecting, sorting, grouping existing data, and summarizing and presenting it in a narrative form. The presentation of the results of qualitative data analysis is made in the form of a short description, or a table adapted to the nature of the data being analyzed.

\section{RESULTS AND DISCUSSION Questionnaire Results}

Based on the questionnaires that have been distributed to fifth-grade students of SD Muhammadiyah 1 Malang, SD Muhammadiyah 4 Malang, SD Muhammadiyah 6 Malang, and SDN 1 Tlogomas, 40 responses from the four classes were obtained, the number is the same as the number of samples that have been determined. The results showed that the application of the Citra Application 
to facilitate the process of identifying elements of folklore in elementary school students in Malang showed very positive results. Details of the research results can be seen in Table 1 below.

Table 1. Survey results before the Citra Application to be are Applied

\begin{tabular}{|c|c|c|c|c|c|c|c|c|}
\hline \multirow[b]{2}{*}{ No } & \multirow{2}{*}{$\begin{array}{c}\text { General } \\
\text { understanding of } \\
\text { Folklore }\end{array}$} & \multicolumn{4}{|c|}{ Scale } & \multirow{2}{*}{$\begin{array}{l}\text { Highest } \\
\text { Percentage } \\
\text { Scale }\end{array}$} & \multirow[b]{2}{*}{ Average } & \multirow[b]{2}{*}{ Category } \\
\hline & & $\begin{array}{l}\text { Strongly } \\
\text { Disagree }\end{array}$ & Disagree & $\begin{array}{l}\text { Agree } \\
\text { Strongly } \\
\text { Agree }\end{array}$ & $\begin{array}{l}\text { Strongly } \\
\text { Agree }\end{array}$ & & & \\
\hline 1 & $\begin{array}{l}\text { Studying folklore } \\
\text { at school in } \\
\text { Indonesian } \\
\text { subjects }\end{array}$ & 0 & 1 & 30 & 9 & $75 \%$ & & Agree \\
\hline 2 & $\begin{array}{l}\text { There are } 5 \text { types } \\
\text { of folklore, namely } \\
\text { (1) fables, (2) } \\
\text { myths, (3) legends, } \\
\text { (4) sage, and (5) } \\
\text { witty stories. }\end{array}$ & 0 & 2 & 18 & 20 & $50 \%$ & & $\begin{array}{l}\text { Strongly } \\
\text { agree }\end{array}$ \\
\hline 3 & $\begin{array}{l}\text { Folklore conveys } \\
\text { messages and } \\
\text { messages that are } \\
\text { beneficial to the } \\
\text { reader or listener }\end{array}$ & 1 & 4 & 18 & 17 & $45 \%$ & & Agree \\
\hline 4 & $\begin{array}{l}\text { Folklore can } \\
\text { help develop } \\
\text { imagination }\end{array}$ & 0 & 10 & 9 & 21 & $52,5 \%$ & & $\begin{array}{l}\text { Strongly } \\
\text { agree }\end{array}$ \\
\hline 5 & $\begin{array}{l}\text { Understanding } \\
\text { folklore, especially } \\
\text { on the types of } \\
\text { folklore }\end{array}$ & 1 & 4 & 20 & 15 & $50 \%$ & $49 \%$ & Agree \\
\hline 6 & $\begin{array}{l}\text { Books and the } \\
\text { internet can } \\
\text { make it easier } \\
\text { to understand } \\
\text { folklore }\end{array}$ & 1 & 3 & 10 & 26 & $65 \%$ & & $\begin{array}{l}\text { Strongly } \\
\text { agree }\end{array}$ \\
\hline 7 & $\begin{array}{l}\text { Never use folklore } \\
\text { apps }\end{array}$ & 9 & 6 & 10 & 15 & $37,5 \%$ & & $\begin{array}{l}\text { Strongly } \\
\text { agree }\end{array}$ \\
\hline 8 & $\begin{array}{l}\text { If there is } \\
\text { a folklore } \\
\text { application, the } \\
\text { application does } \\
\text { not need to be } \\
\text { connected to the } \\
\text { internet when } \\
\text { using it }\end{array}$ & 2 & 5 & 13 & 20 & $50 \%$ & & $\begin{array}{l}\text { Strongly } \\
\text { agree }\end{array}$ \\
\hline
\end{tabular}




\begin{tabular}{|c|c|c|c|c|c|c|c|}
\hline 9 & $\begin{array}{l}\text { Folklore can be } \\
\text { read by anyone }\end{array}$ & 1 & 4 & 15 & 20 & $50 \%$ & $\begin{array}{c}\text { Strongly } \\
\text { agree }\end{array}$ \\
\hline 10 & $\begin{array}{l}\text { Learning folklore } \\
\text { is very important } \\
\text { to express ideas or } \\
\text { ideas }\end{array}$ & 2 & 3 & 17 & 18 & $45 \%$ & $\begin{array}{c}\text { Strongly } \\
\text { agree }\end{array}$ \\
\hline
\end{tabular}

Based on the data in Table 1, initial information was obtained regarding students' understanding of Indonesian language learning. SK \& KD identify folklore in elementary schools. A total of 30 and 9 students responded agreeing and strongly agreeing to questions about folklore in Indonesian subjects. This indicates that folklore has an important role in Indonesian language subjects contained in the curriculum at the elementary school level (Anatasya et al., 2007; Farhurohman, 2017; Hidayat, 2012). The process of identifying folklore is one of the listening skills that must also be mastered by students. Listening is one way for students to learn to focus on reading as well as a process in processing oral symbols (Kurniaman \& Huda, 2018; Satria, 2017; Triyadi, 2015), which in turn can foster understanding, attention to students and can grow appreciation on understanding the meaning of communication to be conveyed non-verbally (Tarigan, 2014; Vuri, 2016).

The existence of folklore in Indonesian subjects has been proven by the results of questionnaires number 2 and 3 in Table 1, a total of $50 \%$ and $45 \%$ of students strongly agree that folklore is part of Indonesian language subjects. As part of oral literature contained in Indonesian language subjects, folklore has eight functions, namely: (1) as a projection system; (2) as a means of social validation; (3) as a tool to enforce social norms; (4) as a tool for children's education; (5) provide a path that is justified by the community; (6) as a means of education; (7) as a promoter of a sense of solidarity in society; and (8) as a reinforcer of cultural values prevailing in society (Anafiah, 2015; Parmini, 2015; Widyahening \& Rahayu, 2021). Questions in numbers 7 and 8 indicate that there are student expectations regarding applications that are easy to use, and are not connected to the internet network when using them (Kastolani, 2015; Muhtar, 2017; Munawar \& Sufa'atin, 2015; Parinsi \& Ratumbuisang, 2017). This is evidenced by the number of responses as much as $37.5 \%$ and $50 \%$ who stated that they strongly agree with the presence of an application that facilitates the learning of folklore so that the creation and application of the Citra Application need to be done. 
Based on the results of the questionnaire listed in Table 1, an application is needed that can facilitate the learning process to identify elements of folklore. The application that has been created is called the Citra Application, it is hoped that the presence of this application can support Indonesian language learning, especially about identifying elements of folklore. This is evidenced by the results of the student questionnaire as shown in Table 2 below.

Tabel 2. Survey results after Application Applied

\begin{tabular}{|c|c|c|c|c|c|c|c|c|}
\hline \multirow[b]{2}{*}{ No } & \multirow{2}{*}{$\begin{array}{c}\text { General } \\
\text { understanding of } \\
\text { Folklore }\end{array}$} & \multicolumn{4}{|c|}{ Scale } & \multirow{2}{*}{$\begin{array}{l}\text { Highest } \\
\text { Percentage } \\
\text { Scale }\end{array}$} & \multirow[t]{2}{*}{ Average } & \multirow[b]{2}{*}{ Category } \\
\hline & & $\begin{array}{l}\text { Strongly } \\
\text { Disagree }\end{array}$ & Disagree & $\begin{array}{l}\text { Agree } \\
\text { Strongly } \\
\text { Agree }\end{array}$ & $\begin{array}{l}\text { Strongly } \\
\text { Agree }\end{array}$ & & & \\
\hline 1 & $\begin{array}{l}\text { Folklore is a story } \\
\text { that comes from the } \\
\text { Indonesian people } \\
\text { which has been } \\
\text { inherited orally }\end{array}$ & 1 & 3 & 12 & 24 & $60 \%$ & $60 \%$ & $\begin{array}{l}\text { Strongly } \\
\text { agree }\end{array}$ \\
\hline 2 & $\begin{array}{l}\text { Folklore is very } \\
\text { important for } \\
\text { students, especially } \\
\text { in Indonesian } \\
\text { language lessons. }\end{array}$ & 2 & 8 & 10 & 20 & $50 \%$ & & $\begin{array}{l}\text { Strongly } \\
\text { agree }\end{array}$ \\
\hline 3 & $\begin{array}{l}\text { Students only know } \\
\text { legend type folklore }\end{array}$ & 7 & 5 & 18 & 10 & $45 \%$ & & Agree \\
\hline 4 & $\begin{array}{l}\text { The appearance/ } \\
\text { design of the Citra } \\
\text { Application is } \\
\text { attractive. }\end{array}$ & 1 & 3 & 10 & 26 & $65 \%$ & & $\begin{array}{l}\text { Strongly } \\
\text { agree }\end{array}$ \\
\hline 5 & $\begin{array}{l}\text { The Citra } \\
\text { application has } \\
\text { complete content } \\
\text { such as materials, } \\
\text { comics, and } \\
\text { games that are } \\
\text { not yet found in } \\
\text { other folklore } \\
\text { applications. }\end{array}$ & 1 & 5 & 15 & 19 & $47,5 \%$ & & $\begin{array}{l}\text { Strongly } \\
\text { agree }\end{array}$ \\
\hline 6 & $\begin{array}{l}\text { The contents of the } \\
\text { Citra Application } \\
\text { have exciting } \\
\text { games so that they } \\
\text { can enrich the } \\
\text { understanding of } \\
\text { folklore }\end{array}$ & 0 & 0 & 18 & 22 & $55 \%$ & & $\begin{array}{l}\text { Strongly } \\
\text { agree }\end{array}$ \\
\hline
\end{tabular}




\begin{tabular}{|c|c|c|c|c|c|c|c|}
\hline 7 & $\begin{array}{l}\text { The material on the } \\
\text { Citra Application } \\
\text { is useful because } \\
\text { it displays the } \\
\text { definition of } \\
\text { folklore along with } \\
\text { examples that can } \\
\text { help understand } \\
\text { folklore }\end{array}$ & 0 & 0 & 15 & 25 & $62,5 \%$ & $\begin{array}{l}\text { Strongly } \\
\text { agree }\end{array}$ \\
\hline 8 & $\begin{array}{l}\text { The Citra } \\
\text { application is very } \\
\text { useful in learning. }\end{array}$ & 0 & 0 & 10 & 30 & $75 \%$ & $\begin{array}{c}\text { Strongly } \\
\text { agree }\end{array}$ \\
\hline 9 & $\begin{array}{l}\text { The existence of the } \\
\text { Citra application } \\
\text { in learning is very } \\
\text { helpful for students } \\
\text { in understanding } \\
\text { folklore }\end{array}$ & 0 & 0 & 8 & 32 & $80 \%$ & $\begin{array}{c}\text { Strongly } \\
\text { agree }\end{array}$ \\
\hline
\end{tabular}

Based on the results of the questionnaire obtained in Table 2, respondents from elementary school students in Malang City can feel the benefits after using the Citra Application. Students find it easier to understand the main learning when doing Indonesian tasks related to identifying elements of folklore. This indicates that the presence of technology in learning is very influential (Hudha et al., 2018; Rizki, et al, 2019; Suyetno \& Yoto, 2021) in creating interesting learning media in the learning process. (Rizki,et al., 2019; Sudrajat et al., 2019; Sukardi, et al, 2019; Widarti \& Asrori, 2021). The initial conditions showed that students did not understand the process of identifying elements of folklore, but through the Citra Application (Folk Stories), students slowly began to understand and know more about how to identify elements of folklore and their functions (Ayu et al., 2019; Lisnawati, 2021; Suryanto \& Waluyo, 2017). In addition, 32 students said that the Citra Application can be learned easily and anytime and anywhere.

The existence of the Citra Application has been able to facilitate learning to identify elements of folklore. This can be seen from users who give positive ratings and comments based on content, materials, comics, and games. This is evident from questionnaire number 5 which shows 34 respondents said agree and strongly agree. Based on the assessment and comments on the Citra application, it indicates that this application has met the requirements as a learning medium that can provide a meaningful experience to students (Anafiah, 2015; Lisnawati, 2021; Widyahening \& Rahayu, 2021). In addition, the content, materials, comics, and games contained in 
the Citra Application can also help to hone understanding of folklore and its types (Anafiah, 2015; Lisnawati, 2021; Widyahening \& Rahayu, 2021). In the material menu, some examples can strengthen the understanding of application users. The content most enjoyed by users of the Citra Application are comics and games. This is because the comic and game content in the application is following the level and interests of students who are still in elementary school (Anzar \& Mardhatillah, 2018; Bachtiar \& Sihes, 2016; Hadi, 2019; Manshur, 2020), thus making one of the advantages of the application. Citra compared to previous applications.

\section{Interview result}

After distributing the questionnaires, the research continued using the interview method. The interview sample was selected using simple random sampling which selected 10 students from each school. The interview consisted of five questions related to the use of the Citra Application as a learning medium. Based on the results of interviews with 40 students who have been selected, it can be concluded that their responses to the application of the Citra Application are very satisfying, pleasant, or positive. The fifth-grade students of SD Muhammadiyah 1 Malang and SD Muhammadiyah 6 Malang stated that the Citra Application had a good appearance, useful materials, and interesting games. In addition, fifth-grade students of SD Muhammadiyah 4 Malang and SDN 1 Tlogomas Malang stated that the application was very interesting, easy to use, useful, fun games, and helped in identifying elements of folklore.

The results of this study have provided information that students can find out more about the process of identifying folklore related to Competency Standard 1 about understanding the explanations of sources and folklore orally. Basic Competencies of class V in KD (1.2) Identify elements of stories about folk tales that they hear. The basic competence is closely related to the Citra Application, where this application is used as a learning medium that can facilitate learning to identify elements of folklore for students. Hudha et al., (2018); Munzil \& Mentari, (2021); Rahayu, et al, (2021) explain that learning media can help accelerate the learning process. In addition, learning media is also a means that can make learning situations more effective (Febrianto, et al, 2020; Fitri \& Zahari, 2019; Kustandi, et al, 2020), and able to improve the quality of the teaching and learning 
process (Munawar \& Sufa'atin, 2015; Susilo, 2020). The teaching and learning process is required to follow $21^{\text {st }}$-century competencies, in order to face more complex challenges accompanied by various knowledge of skills and media and technology (Iqbal, Latifah, \& Irwandani, 2019; Musbhirah, et al, 2018).

As for the results of interviews with fifth-grade elementary school students in Malang related to the appearance and content of the Citra Application, positive and constructive information for the improvement of the application. Starting from the initial appearance of the application, 50\% of students said they were interested in seeing the Citra display because the icons used attractive Citras. This can be seen from the initial appearance of the Citra Application as shown in Figure 1. Based on Figure 1 the initial appearance of an application becomes very decisive because it will be a way to attract users' attention. This is in line with research (Widyahening \& Rahayu, 2021) that learning media used by teachers must be packaged as attractively as possible so that students' learning motivation is higher. In addition, an attractive initial appearance is also one way to increase students' interest in learning participating in learning (Lisnawati, 2021; Widyahening \& Rahayu, 2021).

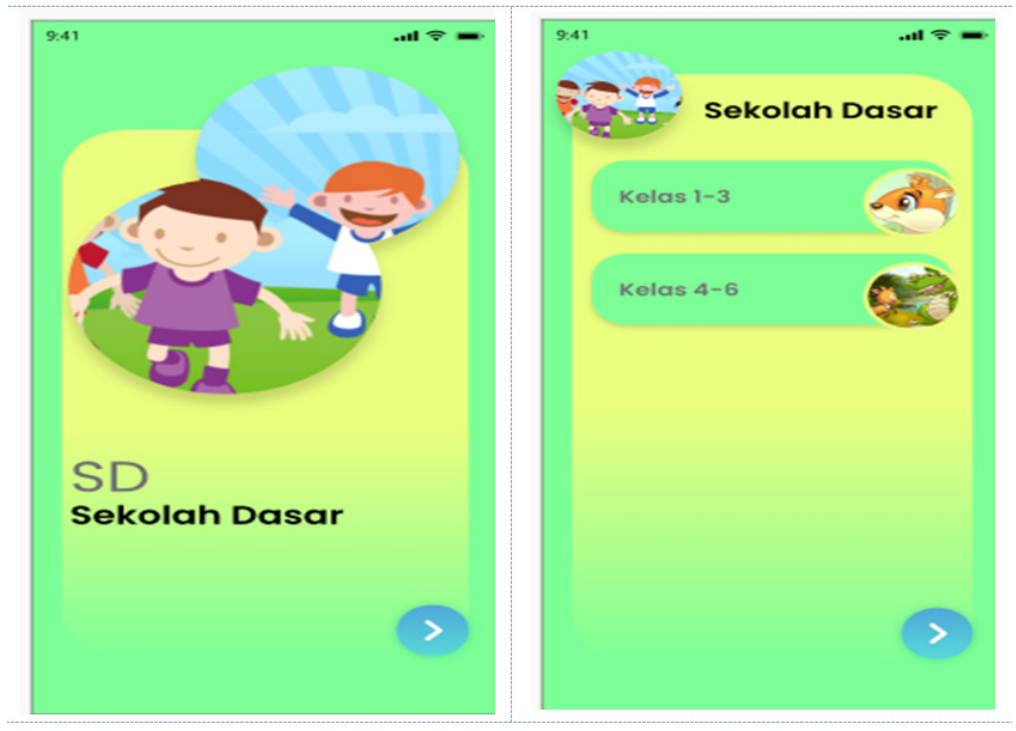

Figure 1. Initial Appearance of the Citra Application (Folk Story)

The results of further interviews conducted on fifth-grade elementary school students in Malang related to the appearance and content of the Citra 
Application obtained constructive information the application. The display of the content section received a lot of positive responses from students as much as $70 \%$. The information obtained from the is the student's desire to immediately open the next page because the display presented is interesting and not boring. This can be seen from the display of the content section of the Citra Application as shown in Figure 2. Based on Figure 2 the display of the content section of the Citra Application presents a folk tale originating from Maluku entitled Sabai Nan Aluih or "Terompah Gajahdoen" and folklore entitled "Batu Belah Batu Betangkup" which comes from Aceh. The display of two folk tales from outside Java became an interesting and new part for students. This further confirms that the learning media used by teachers must present material that attracts students' interest and motivation to learn, one of which is through presenting material that is new to students (Lisnawati, 2021; Widyahening \& Rahayu, 2021). The appearance of folklore that has never been heard by students makes students more interested in opening all views of the Citra Application, especially the content section, which is packaged in comic form.

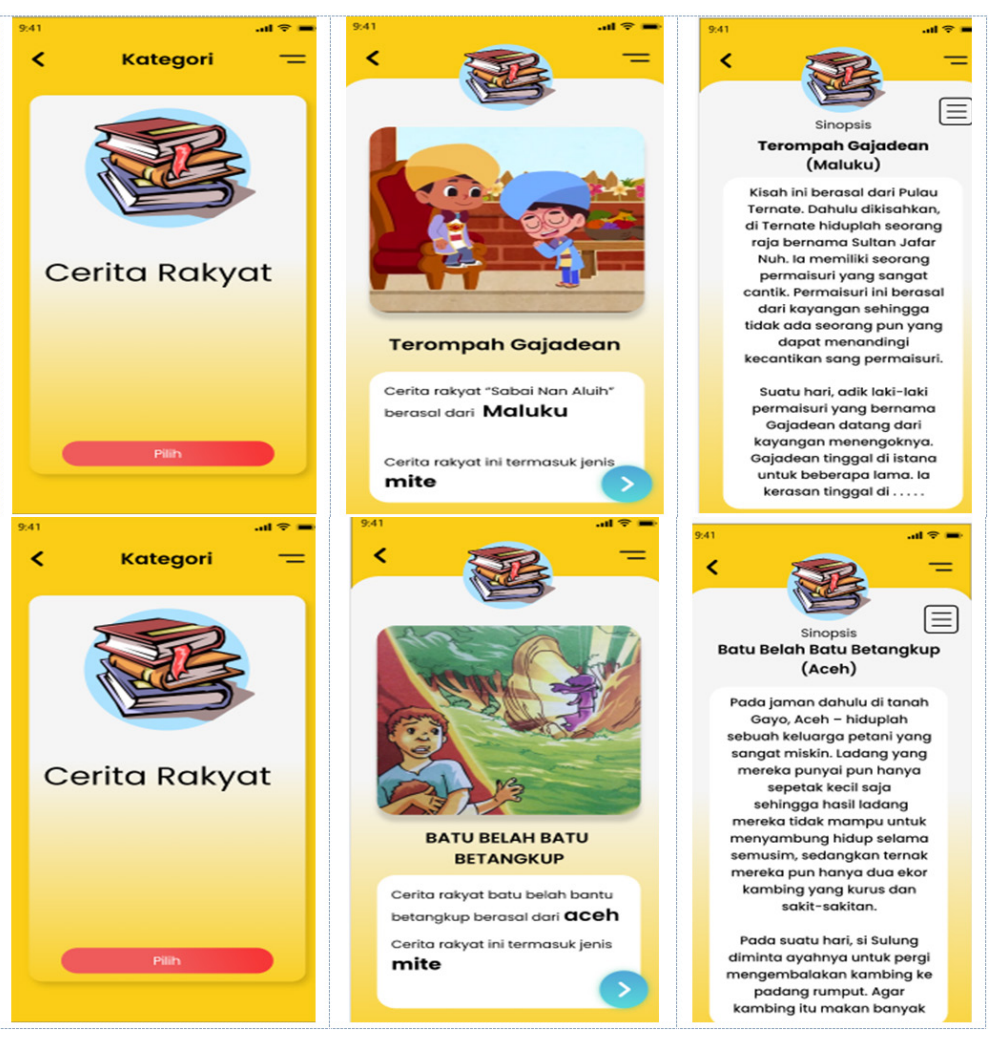

Figure 2. Display of the Contents of the Citra Application (Folk Stories) Packaged in Comic Form 
Further interviews conducted on fifth-grade elementary school students in Malang related to the appearance of the evaluation section in the form of games from the Citra Application obtained very positive information for the improvement of the application. The display of the evaluation section in the form of games received many positive responses from students as much as $75 \%$. The information obtained from the interviews is that students feel happy and don't get bored easily in answering the questions presented in the Citra Application. This can be seen from the display of the evaluation section in the form of a game from the Citra Application as shown in Figure 3. Based on Figure 3, the display of the evaluation section in the form of a game from the Citra Application presents a varied and not monotonous form of evaluation. The display of the evaluation section in the form of a game from the Citra Application is one of the interesting and new sections for students because many variations are presented so that it attracts students' interest to open and answer questions in it. This further emphasizes that the learning media used by teachers must be varied and not monotonous, one of which is through the presentation of various forms of evaluation in the form of games (Lisnawati, 2021; Widyahening \& Rahayu, 2021).

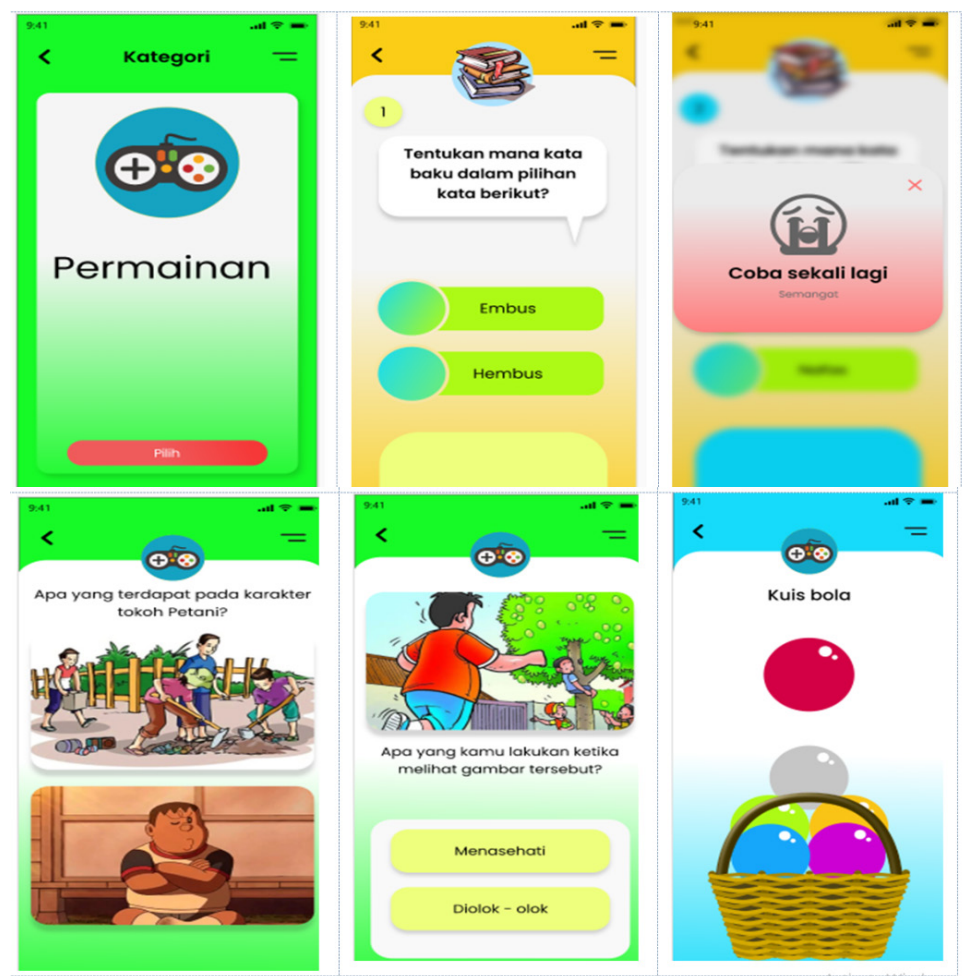

Figure 3. Display of the Citra Application Evaluation Section (Folk Stories) Packaged in Various Forms 


\section{CONCLUSION}

In this study, the application of the Citra Application to facilitate the identification of folklore elements in elementary school students in Malang is the main focus. The results of the study indicate that the application of the Citra Application can facilitate understanding of the elements of folklore in Indonesian language learning. In addition, the existence of the Citra Application can also act as a learning medium that can provide useful benefits to students. Students can be easily understand the elements of folklore through the content contained in the Citra Application, such as materials, comics, and evaluation in the form of games. These contents are not found in other folklore applications. This application can help students who want to identify folklore. With this application, students can learn folklore anytime and anywhere because it is easily accessible. Therefore, it is recommended that teachers and students use the Citra Application to learn Indonesian SK \& KD Folklore to facilitate an understanding of the elements of folklore. 


\section{REFERENCES}

Aini, S. N., \& Nugraheni, A. S. (2021). Analisis Kemampuan Baca Tulis Melalui Media Pembelajaran Cerita Rakyat pada Siswa Kelas IV Sekolah Dasar. DEIKSIS, 13(2), 197-203. https://doi.org/http://dx.doi.org/10.30998/ deiksis.v13i2.6485

Anafiah, S. (2015). Pemanfaatan Cerita Rakyat Sebagai Alternatif Bacaan BAGI Anak. Trihayu: Jurnal Pendidikan Ke-SD-An, 1(2), 128-133. https://doi. org/https://doi.org/10.30738/trihayu.v1i2.839

Anatasya, D., Yanti, F. W., Mellenia, R., Angreska, R., Putri, S., Kuntarto, E., \& Noviyanti, S. (2007). Pembelajaran Bahasa Indonesia di Sekolah Dasar. Jurnal Kajian Kebahasaan, 1-9. Retrieved from https://d1wqtxts1xzle7. cloudfront.net/57895911/Artikel_Jurnal_Tugas_Mk_Kajian_ Kebahasaan-with-cover-page-v2.pdf?Expires $=1629165934 \&$ Signature $=\mathrm{C}$ w7H0kYp MUUR x056DwkmeENDaU1MMQc-uV3 9rK68Mfrv-oIdf Vnev82hEPotL5fh7ZWGaQc6e NVNJNBSM74bdZUn IH0hK6 9MLG FIb4Wkfqr

Anzar, S. F., \& Mardhatillah, M. (2018). Analisis Kesulitan Belajar Siswa Pada Pembelajaran Bahasa Indonesia di Kelas V SD Negeri 20 Meulaboh Kabupaten Aceh Barat Tahun Ajaran 2015/2016. Bina Gogik: Jurnal Ilmiah Pendidikan Guru Sekolah Dasar, 4(1). Retrieved from https://ejournal. stkipbbm.ac.id/index.php/pgsd/article/view/25

Asrial, A., Syahrial, S., Kurniawan, D. A., \& Amalina, N. (2019). Analisis hubungan kompetensi bahasa indonesia terhadap kompetensi pedagogik mahasiswa pendidikan guru sekolah dasar. Premiere Educandum: Jurnal Pendidikan Dasar Dan Pembelajaran, 9(1), 1-8. https:/ / doi.org/http:/ / doi. org/10.25273/pe.v9i1.2832

Ayu, R. F. K., Sari, S. P., Setiawan, B. Y., Fitriyah, F. K., \& others. (2019). Meningkatkan Kemampuan Berbahasa Daerah Melalui Cerita Rakyat Digital pada Siswa Sekolah Dasar: Sebuah Studi Pengembangan. Child Education Journal, 1(2),65-72.https:/ / doi.org/https://doi.org/10.33086/ cej.v1i2.1356

Azis, A. (2018). Implementasi gerakan literasi sekolah pada pembelajaran bahasa Indonesia di sekolah dasar. Autentik: Jurnal Pengembangan Pendidikan Dasar, 2(1), 57-64. Retrieved from https://autentik.stkippgrisumenep. ac.id/index.php/autentik/article/view/22 
Bachtiar, E. S. B., \& Sihes, A. J. (2016). Kompetensi kognitif pembelajaran apresiasi sastra di Sekolah Dasar. Jurnal Penelitian Bahasa Dan Sastra Indonesia V2. I1, 1, 11 .

Bermawi, Y., \& Fauziah, T. (2016). Penerapan Pendekatan Saintifik dalam Pembelajaran di Sekolah Dasar Aceh Besar. Jurnal Pesona Dasar, 2(4), 63-71. Retrieved from http://www.e-repository.unsyiah.ac.id/PEAR/ article/view/7533

Dasem, A. A., Laka, B. M., \& Niwele, A. (2018). Peranan guru dalam proses pembelajaran bahasa Indonesia di SD inpres komboi kabupaten biak numfor. WACANA AKADEMIKA: Majalah Ilmiah Kependidikan, 2(2), 126136. https:/ / doi.org/https:/ / doi.org/10.30738/wa.v2i2.2596

Dewi, T. K., \& Yuliana, R. (2018). Pengembangan media pembelajaran scrapbook materi karangan deskripsi mata pelajaran bahasa indonesia kelas III sekolah dasar. Refleksi Edukatika: Jurnal Ilmiah Kependidikan, 9(1), 19-25. https://doi.org/https:/ / doi.org/10.24176/re.v9i1.2804

Farhurohman, O. (2017). Implementasi Pembelajaran Bahasa Indonesia di SD/MI. Primary: Jurnal Keilmuan Dan Kependidikan Dasar, 9(1), 23-34. Retrieved from http://www.jurnal.uinbanten.ac.id/index.php/primary/article/view/412

Febrianto, P. T., Mas'udah, S., \& Megasari, L. A. (2020). Implementation of online learning during the covid-19 pandemic on Madura Island, Indonesia. International Journal of Learning, Teaching and Educational Research, 19(8), 233-254. https://doi.org/10.26803/ijlter.19.8.13

Fitri, S., \& Zahari, C. L. (2019). The implementation of blended learning to improve understanding of mathematics. In P. P.W. (Ed.), 6th Seminar Nasional Pendidikan Matematika Universitas Ahmad Dahlan 2018, SENDIKMAD 2018 (Vol. 1188). Universitas Negeri Medan, Willem Iskandar Street, Pasar V Medan Estate, Medan, North Sumatera, Indonesia: Institute of Physics Publishing. https://doi.org/10.1088/1742-6596/1188/1/012109

Hadi, S. (2019). Problematik Pendidikan Bahasa Indonesia Kajian Pembelajaran Bahasa Indonesia pada Sekolah Dasar. Jurnal Pendidikan: Riset Dan Konseptual, 3(4), 74-78. https:/ / doi.org/https:/ / doi.org/10.28926/riset_ konseptual.v3i1.108

Handayani, E. S., \& Subakti, H. (2021). Pengaruh Disiplin Belajar terhadap Hasil Belajar Bahasa Indonesia di Sekolah Dasar. Jurnal Basicedu, 5(1), 151-164. https://doi.org/https:/ / doi.org/10.31004/ basicedu.v5i1.633 
Harlina, H., \& Wardarita, R. (2020). Peran Pembelajaran Bahasa dalam Pembentukan Karakter Siswa Sekolah Dasar. Jurnal Bindo Sastra, 4(1), 63-68. https://doi.org/https:/ / doi.org/10.32502/jbs.v4i1.2332

Hidayah, N. (2015). Penanaman Nilai-Nilai Karakter dalam Pembelajaran Bahasa Indonesia di Sekolah Dasar. TERAMPIL: Jurnal Pendidikan Dan Pembelajaran Dasar, 2(2), 190-204. https://doi.org/https://doi. org/10.24042/terampil.v2i2.1291

Hidayat, D. (2012). Pentingnya Pelajaran Bahasa Indonesia pada Tingkat Pendidikan Dasar SD dan SMP Terintegrasi dengan Pelajaran Lain (Fenomena yang Terjadi di Sekeliling Siswa). Paradigma Lingua, 1(2). Retrieved from http://www.openjournal.unpam.ac.id/index.php/ Paradigma/article/view/401

Hidayat, R., Khotimah, K., \& Saputra, A. (2019). Mata Kuliah Wajib Umum Bahasa Indonesia di Perguruan Tinggi: Sebuah Tawaran Model Pembelajaran. Jurnal Ilmiah Telaah, 4(1), 31-35. https:/ / doi.org/https:/ / doi.org/10.31764/telaah.v4i1.1268

Hudha, M. N., Chaeruman, U. A., Aji, S. D., Huda, C., Yusro, A. C., Kumala, F. N., .. Abdullah, A. G. (2018). SPADA: Online learning between universities of PGRI Indonesia. In N. A.B.D. \& A. A.G. (Eds.), 3rd Annual Applied Science and Engineering Conference, AASEC 2018 (Vol. 197). Physics Education Study Program, Universitas Kanjuruhan Malang, Jl. S. Supriadi no 48, Malang, 65148, Indonesia: EDP Sciences. https:/ / doi. org/10.1051/matecconf/201819703002

Iqbal, M., Latifah, S., \& Irwandani, I. (2019). Pengembangan Video Blog (Vlog) Channel Youtube Dengan Pendekatan Stem Sebagai Media Alternatif Pembelajaran Daring. Inovasi Pembangunan: Jurnal Kelitbangan, 7(2), 135.

Kastolani, W. (2015). Pengembangan model pembelajaran sts (science-technology society) untuk meningkatkan kepedulian mahasiswa terhadap lingkungan hidup pada matakuliah ekologi manusia. Jurnal Penelitian Pendidikan, 15(1), 1-9. https://doi.org/https://doi.org/10.17509/jpp. v15i1.1279

Kurniaman, O., \& Huda, M. N. (2018). Penerapan Strategi Bercerita Untuk Meningkatkan KeterampilanMenyimakSiswa Kelas IIISD Muhamadiyah 6 Pekanbaru. Primary: Jurnal Pendidikan Guru Sekolah Dasar, 7(2), 249-255. 
Kustandi, C., Fadhillah, D. N., Situmorang, R., Prawiradilaga, D. S., \& Hartati, S. (2020). VR use in online learning for higher education in Indonesia. International Journal of Interactive Mobile Technologies, 14(1), 31-47. https:/ / doi.org/10.3991/ijim.v14i01.11337

Lisnawati, L. (2021). Pengembangan Modul Cerita Rakyat Terintegrasi Latar Cerita Daerah Sulawesi Selatan pada Siswa Sekolah Dasar. Pedagogik Journal of Islamic Elementary School, 4(1), 59-74. https:/ / doi.org/https:/ / doi.org/10.24256/ pijies.v4i1.1824

Manshur,S.S.(2020).PengembanganLKSTematikBahasaIndonesiaKelas VMelalui Kegiatan Lesson Study Di Sekolah Dasar. Jurnal Cakrawala Pendas, 6(1), 1522. Retrieved from https://www.researchgate.net/profile/MuhardilaFauziah/publication/343377230_PENGEMBANGAN_LKS_TEMATIK_ BAHASA_INDONESIA_KELAS_V_MELALUI_KEGIATAN_LESSON_ STUDY_DI_SEKOLAH_DASAR/links/5fbd2ecaa6fdcc6cc66332c7/ PENGEMBANGAN-LKS-TEMATIK-BAHASA-INDONESIA-KELAS-V-

Mansyur, U. (2018). Pembelajaran Inovatif Bahasa Indonesia di Sekolah Dasar. Jurnal Fakultas Sastra. Universitas Muslim Indonesia, 6(1), 1-9. Retrieved from https://d1wqtxts1xzle7.cloudfront.net/67035975/downloadwith-cover-page-v2.pdf?Expires=1629165454\&Signature=ZYv4wQY wnOSkaTtJpHIo5gPEzSIIBuS-6GbF6MHQYJg9eJ13yctDvSqQ1KV1 ylNGwjp2dleI41RsgELEhzoCKcqdLp6kgcapYR0NkOPvQ6J7Mraw〜R7xcZPOxg4XglXYvGFiuWWDqqK5ZbZI8hY

Muhtar, A. A. (2017). Developing Online Course Portal to Improve Teachers' Competency in Creating Action Research (CAR) Proposal Using Learning Management System (LMS) Moodle. In A.S., H. T., R. L.S., K. D., N. A.B.D., S. E., ... I. M. (Eds.) (Vol. 812). Science Teacher, Wira Bhakti Senior High School, Jl. Nani Wartabone, Bonebolango, 96184, Indonesia: Institute of Physics Publishing. https:/ / doi.org/10.1088/1742-6596/812/1/012076

Mulyana, A. T. (2018). Model Pengembangan Bahan Ajar Bahasa Indonesia sebagai Mata Kuliah Wajib Umum (MKWU) Berbasis Paradigma Pembelajaran Abad Ke-21 pada Aspek Career and Life Skills (CLS). Jurnal Inovasi Pendidikan MH Thamrin, 2(2), 43-54. https:/ / doi.org/https:/ / doi. org/10.37012/jipmht.v2i2.42

Munawar, \& Sufa'atin. (2015). Pembangunan Aplikasi Media Pembelajaran Dan Simulasi Troubleshooting Televisi. Komputa: Jurnal Ilmiah Komputer Dan Informatika, 4(1), 1-6. Retrieved from https://repository.unikom. ac.id/30304/ 
Munzil, M., \& Mentari, P. R. A. (2021). Development of e-learning teaching material with augmented reality based on problem-based learning for nature of chemistry and scientific methods topic as teaching material in Covid-19 pandemic. In S. H., H. H., \& R. D. (Eds.), 4th International Conference on Mathematics and Science Education: Innovative Research in Science and Mathematics Education in the Disruptive Era, ICoMSE 2020 (Vol. 2330). Department of Chemistry, Faculty of Mathematics and Natural Sciences, State University of Malang, J1. Semarang No. 5, Malang, East Java, 65145, Indonesia: American Institute of Physics Inc. https://doi. org/10.1063/5.0043248

Musbhirah, Q. U., Muntari, M., \& Al Idrus, S. W. (2018). Pengaruh Model Pembelajaran Joyful Learning dengan Media Kartu Aksi Terhadap Hasil Belajar Kimia. Chemistry Education Practice, 1(1), 26-33.

Ngumpriyatun, N. (2020). Penggunaan metode talking ball untuk meningkatkan keterampilan bercerita pada mata pelajaran bahasa Indonesia di sekolah dasar. Autentik: Jurnal Pengembangan Pendidikan Dasar, 4(1), 25-32. https:/ / doi.org/ttps:/ / doi.org/10.36379/autentik.v4i1.47

Nurdiyanti, E., \& Suryanto, E. (2010). Pembelajaran literasi mata pelajaran bahasa indonesia pada siswa kelas V sekolah dasar. Paedagogia, 13(2), 115-128. Retrieved from https://jurnal.fkip.uns.ac.id/index.php/paedagogia/ article/view/153

Parinsi, M. T., \& Ratumbuisang, K. F. (2017). Indonesian mobile learning information system using social media platforms. International Journal of Mobile Computing and Multimedia Communications, 8(2), 44-67. https:// doi.org/10.4018/IJMCMC.2017040104

Parmini, N. P. (2015). Eksistensi cerita rakyat dalam pendidikan karakter siswa SD di Ubud. Jurnal Kajian Bali, 5(02), 441-460.

Rahayu, Y., Ahmad, H. A., \& Alamsyah, I. M. (2021). The implementation of tpack framework in mathematics mobile edugame design: Basic multiplication and division concept. In R. B.N., R. J., P. A., F. A.N., A. M., P. R.C.I., ... S. K.A. (Eds.), 10th International Conference and Workshop on High Dimensional Data Analysis, ICW-HDDA 2020 (Vol. 1722). Faculty of Art and Design, Institut Teknologi Bandung, Jl. Ganesha no. 10, Bandung, 40132, Indonesia: IOP Publishing Ltd. https://doi.org/10.1088/17426596/1722/1/012029 
Riyanton, M. R. M., \& Wijayawati, D. (2020). Pembelajaran Bahasa Indonesia Berbasis Minat Membaca Dan Literasi Di Sekolah Dasar. Prosiding, 9(1), 274-284. Retrieved from http://www.jurnal.lppm.unsoed.ac.id/ojs/ index.php/Prosiding/article/view/1190

Rizki, Mulyani, S., Ramadhanu, A., Permata Sari, D., Husna Arsyah, R., \& Sri Wahyuni Nengsih, N. (2019). Convergence Analysis of Acceleration and Generalization of E-Learning in the Manifestation of Globalization Education Readiness 4.0. In R. R., D. R., H. B., \& M. A. (Eds.), 1st International Conference Computer Science and Engineering, IC2SE 2019 (Vol. 1339). Universitas Putera Indonesia YPTK Padang, Padang, Indonesia: Institute of Physics Publishing. https://doi.org/10.1088/17426596/1339/1/012078

Satria, T. G. (2017). Meningkatkan Keterampilan Menyimak Melalui Pendekatan Saintifik Pada Anak Kelas Iv Jakarta Barat. Jurnal PGSD: Jurnal Ilmiah Pendidikan Guru Sekolah Dasar, 10(2), 114-120. https:/ / doi.org/https:/ / doi.org/10.33369/pgsd.10.2.114-120

Simbolon, N. (2016). Meningkatkan Kemampuan Membaca Pemahaman Dengan Menggunakan Model Pembelajaran CIRC (Cooperative Integrated Reading And Composition) Pada Pelajaran Bahasa Indonesia Di Sekolah Dasar. Jurnal Mutiara Pendidikan Indonesia, 1(1), 58-69. Retrieved from ttp:/ / e-journal.sari-mutiara.ac.id/index.php/JMT/article/view/87

Sudrajat, D., Achdisty, M., Kurniasih, N., Roslina, Parwito, Mulyati, S., ... Sallu, S. (2019). The Implementation of Innovation in Educational Technology to Improve the Quality of Website Learning in Industrial Revolution Era 4.0 Using Waterfall Method. In 2018 1st Workshop on Engineering, Education, Applied Sciences, and Technology, WEAST 2018 (Vol. 1364). Informatics Engineering, STMIK IKMI Cirebon, Jawa Barat, Indonesia: Institute of Physics Publishing. https:/ / doi.org/10.1088/1742-6596/1364/1/012044

Sukardi, Giatman, M., Haq, S., Sarwandi, \& Pratama, Y. F. (2019). Effectivity of Online Learning Teaching Materials Model on Innovation Course of Vocational and Technology Education. In I. I., Y. Y., K. K., \& R. R. (Eds.), 1st International Conference on Education, Science and Technology 2019, ICESTech 2019 (Vol. 1387). Faculty of Engineering, Universitas Negeri Padang, Indonesia: Institute of Physics Publishing. https://doi. org/10.1088/1742-6596/1387/1/012131 
Suryanto, E., \& Waluyo, B. (2017). Pembelajaran Apresiasi Cerita Rakyat Bermedia Wayang Kancil. Indonesian Language Education and Literature, 3(1), 66-78. Retrieved from https://web.archive.org/web/20180411023118id_/ http://syekhnurjati.ac.id/jurnal/index.php/jeill/article/ viewFile/1700/1375

Susilo, S. V. (2020). Penggunaan Media Pembelajaran Berbasis Audio Visual Untuk Meningkatkan Hasil Belajar Bahasa Indonesia Di Sekolah Dasar. Jurnal Cakrawala Pendas, 6(2), 108-115. Retrieved from https:// www.researchgate.net/profile/sigit-susilo/publication/343377300_ penggunaan_media_pembelajaran_berbasis_audio_visual_untuk_ meningkatkan_hasil_belajar_bahasa_indonesia_di_sekolah_dasar / links/5f817238a6fdccfd7b5555eb/penggunaan-media-pembelajaran-ber

Susilo, S. V., \& Ramdiati, T. (2019). Penerapan Model Multiliterasi Untuk Meningkatkan Keterampilan Menulis Karangan Persuasi Pada Mata Pelajaran Bahasa Indonesia DiSekolah Dasar. Jurnal Cakrawala Pendas, 5(1), 24-31. Retrieved from https://www.neliti.com/publications/280137/ penerapan-model-multiliterasi-untuk-meningkatkan-keterampilanmenulis-karangan-p

Suyetno, A., \& Yoto. (2021). Learning media development based on CNC simulator as the digital tool to support the CNC practice learning during COVID-19 new normal. In R. F., H. D., H. M.L., M. A., H. H., N. D., ... Nurhidayat (Eds.), 6th International Conference on Technology and Vocational Teachers, ICTVT 2020 (Vol. 1833). Faculty of Engineering, Universitas Negeri Malang, Malang, Indonesia: IOP Publishing Ltd. https://doi. org/10.1088/1742-6596/1833/1/012009

Tarigan, H. G. (2014). Menyimak sebagai suatu Keterampilan Berbahasa. Bandung: Angkasa.

Triyadi, S. (2015). Efektivitas Penggunaan Media Audio-Visual Untuk Meningkatkan Keterampilan Menyimak Siswa Pada Mata Pelajaran Pendidikan Bahasa Indonesia. JUDIKA (JURNAL PENDIDIKAN UNSIKA), 3(2), 231-236. Retrieved from https://journal.unsika.ac.id/ index.php/judika/article/view/215/0

Vuri, D. (2016). Penerapan pendekatan pengalaman berbahasa dalam pembelajaran bahasa di sekolah dasar kelas rendah. Jurnal Ilmiah Guru Caraka Olah Pikir Edukatif, 20(1), 24-30. Retrieved from https://journal. uny.ac.id/index.php/cope/article/viewFile/10790/8117 
Werdiningsih, D. (2015). Strategi Metakognisi Pembelajar Anak dalam Pembelajaran Bahasa Indonesia di Sekolah Dasar. Jurnal Cakrawala Pendidikan, 34(1), 107-117. Retrieved from https:/ / repo.iainbatusangkar. ac.id/xmlui/ bitstream/handle/123456789/8070/1509096395462_418110832-1-PB.pdf?sequence=1

Widarti, H. R., \& Asrori, M. R. (2021). The development of Android-based thin layer chromatography learning material with project-based learning. In S. H., H. H., \& R. D. (Eds.), 4th International Conference on Mathematics and Science Education: Innovative Research in Science and Mathematics Education in the Disruptive Era, ICoMSE 2020 (Vol. 2330). Department of Chemistry, Faculty of Mathematic and Natural Science, Universitas Negeri Malang, Jalan Semarang No. 5 Malang, East Java, 65145, Indonesia: American Institute of Physics Inc. https:// doi.org/10.1063/5.0043359

Widyahening, C. E. T., \& Rahayu, M. H. S. (2021). Pembelajaran Kosa Kata Bahasa Inggris dengan Media Cerita Rakyat bagi Siswa Kelas V Sekolah Dasar. Jurnal Komunikasi Pendidikan, 5(1), 108-123. https://doi.org/10.32585/ jkp.v5i1.1076

Youpika, F., \& Zuchdi, D. (2016). Nilai pendidikan karakter cerita rakyat suku Pasemah Bengkulu dan relevansinya sebagai materi pembelajaran sastra. Jurnal Pendidikan Karakter, 6(1), 48-58. https://doi.org/https:// doi.org/10.21831/jpk.v0i1.10731 